\title{
FORMS OF CITIZENS‘ COMMUNICATION WITH THE PUBLIC ADMINISTRATION INSTITUTIONS
}

\begin{abstract}
Globalisation and technological development have caused many changes that force both businesses and governments to react. The development of information and communication technologies has changed the way how people obtain information, communicate, work, buy goods and affect their everyday lives. The revolution of the Internet has opened new opportunities for all economic operators. This process can not be stopped. The government which wants to meet the citizens ' changing demands and needs has to be flexible and adapt to this progress, which results in e-Government. The contribution focuses on the ways of communication between citizens and institutions of public administration and evaluates their satisfaction with provided e-Government services.
\end{abstract}

Keywords: E-Government services, public administration, communication, citizens, satisfaction index.

JEL Classification: H11, M00, F60

\section{Introduction}

The growing importance of information-communication technologies (ICT) in everyday life is a key component of the knowledge society development. The daily use of ICT is not an essential part only for businesses, but also for citizens and governments. The government considers education, science, research and innovation, informatisation and digitalisation as the essential pillars of the knowledge-based society and economy. The reduction of disparities among the citizens as well as of the digital divide is one of the main government responsibilities. To reduce the digital divide means that knowledge becomes ubiquitous and available to everybody without restriction, which affects all sectors of the society. The building of a solid ICT infrastructure should be a part of the government national strategy. Governments should lead by example in the digitisation of the internal and external work as a part of the e-Government strategy. It results in the building and implementation of e-Government, e-services for citizens and e-Governance and becomes an important part of the knowledge society.

\section{Public administration electronisation}

E-Government is an electronic form of public administration in the application of information and communication technologies in public administration processes [1]. The aim of e-Government is to reduce unproductive time spent by dealing with official matters, to minimise error rates and eliminate duplication of the same acts. In the future citizens and businesses will be allowed to arrange official matters in one place or directly from home or office via a computer [2 and 3].

\subsection{The effective, reliable and open public administration}

It has been the largest reform of the state administration since 1989. The aim of the reform is to streamline the functioning, ensure the quality, accessibility and transparency of public administration for citizens [4 and 5]. The implementation of the effective, reliable and open public administration (ESO) will help to reduce costs and optimise the functioning of public administration, simplifying the processing of the official matters for citizens and businesses at the institutions of public administration. Citizen uses the government services at one office which is located near the place of residence. The ESO is a comprehensive reform which was divided into several stages because of its complexity. The aim of the first stage was an integration of the specialised local state administration. The specialised local state administrations were cancelled on January $1^{\text {st }}$,

\footnotetext{
* Jana Stofkova, Katarina Gasova

Faculty of Operation and Economics of Transport and Communications, University of Zilina, Slovakia

E-mail: jana.stofkova@fpedas.uniza.sk
} 


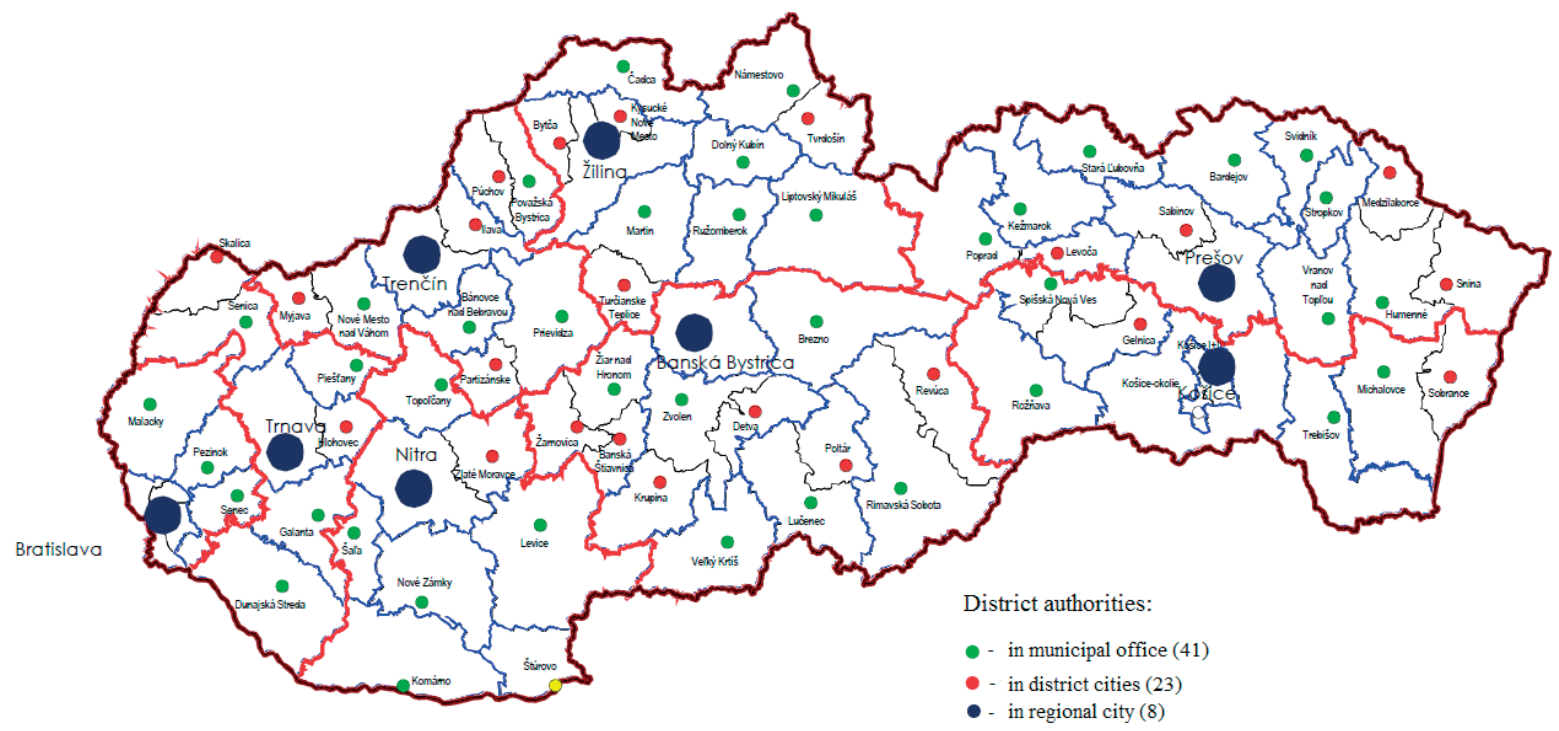

Fig. 1 District authorities created during the ESO reform (Source: [8])

2013 at the regional level. The creation of a uniform and clear structure of the local governments on October $1^{\text {st }}, 2013$ was the essence of the second integration stage. The activities of selected offices of the specialised state administration were concentrated in a government office at the local level. 72 district authorities were established in the Slovak Republic as shown in the following Fig. 1 [6 and 7].

The agenda of district authorities consists of the agenda of original district authorities (local government, business, birth record, misdemeanours, citizenship, etc.) and the agenda of the integrated specialised state administration authorities. 248 district authorities were cancelled: environment, road traffic and roads, forest and cadastral. 49 from original 50 became district authorities. 23 new district authorities were created for an integrated agenda of government and as a base (backoffice) for more accessible services to citizens, which will be provided by the Client centre (front-office). The ESO reform is gradually implemented as follows:

- the integration of the specialised local state administration by mid 2014

- client services centres for citizens - 2014/2015, and

- the state administration optimisation, optimisation of processes and structures of the central public administration authorities and the optimisation of processes and the government performance - from 2014 to 2020 [8 and 9]

\subsection{The Effective public administration 2014-2020}

The managing authority of the Operational programme the Effective public administration is the Ministry of Interior of the Slovak Republic. The working team of the Ministry of
Interior received a financial support from the European Social Fund for the programming period 2014 - 2020 amounting to more than 335 million euros. An ambition of the Operational programme is to provide citizens with necessary public services at every stage of their life or business in financial and time saving manner. The programme aims to provide public services quickly and efficiently in order to promote a sustainable growth, job creation and social inclusion defined in the Europe 2020 strategy. The programme strategy reflects to requirements of the European Union legislation in relevant areas. The implementation of the Operational programme will contribute to meeting the national strategic goal of a modern, professional, efficient, reliable, non-corrupt and transparent public administration in the Slovak Republic in 2020 [9 and 10].

The Operational programme supports two basic aims according to building a customer-oriented, professional and transparent public administration. The first ambition is to support systems and processes of the public administration including institutional capacity strengthening and transparent procurement rules. The second priority is a major reform of the judiciary, streamlining the judicial system and increase law enforcement. The Operational programme covers the whole territory of the Slovak Republic and the main target groups are state authorities, local governments, social partners, civil society organisations, non-governmental organisations, other stakeholders and partners. The government of the Slovak Republic approved the Operational programme Effective public administration by resolution No. 228 on May $14^{\text {th }}, 2014$ [10 and 11]. 


\section{Key access components}

The public is able to communicate with the public administration authorities through various communication channels, e.g.: the Internet, telephone and personal contact. The central access components were built for various communication channels: the central public administration portal, specialised portals, client centres, contact centre and Integrated Citizen Service Points [12].

Central contact centre (call centre) is used to provide telephone information about services and activities of the public authorities. The centre is established and operated by the Government Office of the Slovak Republic. Citizens can obtain information on agendas provided by the district authorities, the addresses and office hours of the integrated public administration authorities and client centres on free phone number 0800222 222. The domicile of the call centre is the Ministry of Interior department in Banska Bystrica. The call center was set up on the internal personnel and technical resources from the Ministry of Interior with zero external costs [12].

The specialised portal is an information system of the public administration which provides electronic official communication with one or more pubic authorities via the Internet [12].

Citizens and businesses who prefer personal contact can visit Client centres [12].

The central public administration portal is a public administration information system of the Slovak Republic available through: www.slovensko.sk. The portal enables citizens to communicate electronically with all public authorities and to access the common modules via the Internet. The Government Office of the Slovak Republic is the administrator of the central portal and is operated by the National agency for network and electronic services (NASES). The portal is divided into the following sections: citizen, business and public administration. [12].

The Slovak post, Inc. is one of the main providers of e-Government services. Services are provided in more than 100 cities in 602 workplaces evenly distributed across the Slovak Republic. Visitors can use a payment system called e-Kolok and public services through Integrated Citizen Service Points [12].

\subsection{The Internet as a suitable communication medium}

The Internet is a global communication network that allows computers worldwide to connect and exchange information. The beginning of its creation is connected to the initiation computer networks projects in 1957. Until today the development of the Internet and information-communication technologies has caused various changes [13].

The Internet brings many advantages e.g. rapid exchange of information, sharing of data services such as Internet banking, e-business, new jobs opportunities and education. We can conclude that the Internet is a suitable communication tool for e-Government services according to its benefits and availability 24/7. However it is necessary to ensure safe and quality e-Government services through the secure broadband connection [14].

Trend in the number of Internet users in the Slovak Republic is increasing every year approximately by $5 \%$. As expressed by the following figure the Internet is currently used by 4477641 Slovak citizens (Fig. 2) [14].

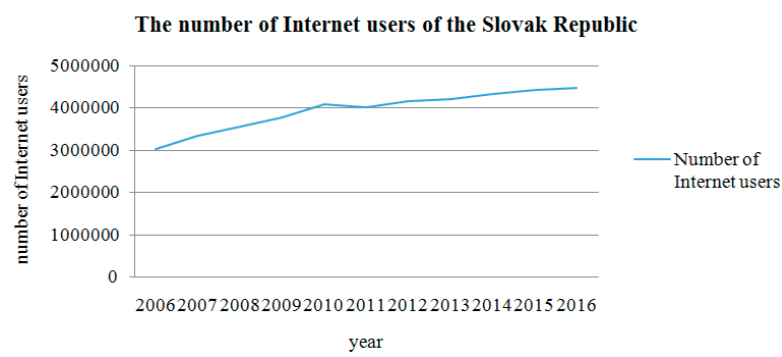

Fig. 2 The number of Internet users of the Slovak Republic (Source: [14])

Currently there are 1273812 fixed and 3685683 mobile broadband connections to the Internet in the Slovak Republic. Steadily increasing number of regular Internet users is undeniable proof that the Internet is a very suitable tool for communication with the public administration [14].

\section{Aim of contribution, material and methods}

Authors aim to introduce e-Government in the Slovak republic and to evaluate citizens' satisfaction with provided e-Government services. Theoretical basis gives a description of public administration electronisation. The current state analysis describes the ESO reform of public administration in the Slovak republic, the key access components and the impact of the Internet. The contribution presents the most used ways of citizens' communication with public administration and the loyalty index, based on results of the current state analysis and citizens' satisfaction survey.

Relevant information sources, necessary for the fulfilment of the aim were used:

domestic and foreign book literature,

scientific contributions and publications,

European Commission report on e-Government, and 
- results of citizens' satisfaction survey carried out by TNS Slovakia.

During the research authors used following methods:

- method of data collection for the theoretical basis creation, method of analysis during the description of current state in the Slovak republic and evaluation of citizens' satisfaction with provided e-Government services,

- indexes method for the loyalty index calculation and presentation of its evolution over time, and

- method of synthesis used for conclusions creation.

Authors used the Excel program for the indexes calculation.

\section{Citizens' satisfaction analysis with the e-Government services}

In December 2014, TNS Slovakia carried out a survey based on the instructions of the Ministry of Finance of the Slovak Republic. 1012 citizens aged from 18 to 65 participated in the satisfaction survey. The survey was designed to provide relevant information about customer satisfaction with e-Government services. The following figure displays the preferred ways of citizens' communication with the public administration institutions (Fig. 3) [15].

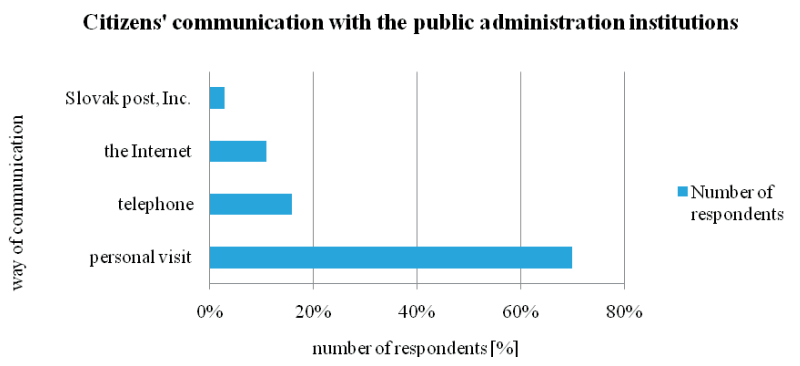

Fig. 3 Citizens' communication with the public administration institutions (Source: [15])

Most of the citizens prefer personal communication with the public administration institutions. This may be caused by the current complexity of the Central portal and imperfections of provided services which require personal retrofit. $16 \%$ of respondents prefer telephone contact and $11 \%$ of respondents prefer electronic form of communication with the public administration. The least used form of communication is through the Integrated Citizen Service Points.

The survey results show that the preferred source of e-Government services information is the Internet search engine and traditional media such as a television and print media. As expressed by the following figure, respondents, who regularly use the Internet, search the most information about the official matters and download sheets and forms from websites of the public administration institutions (Fig. 4) [15].

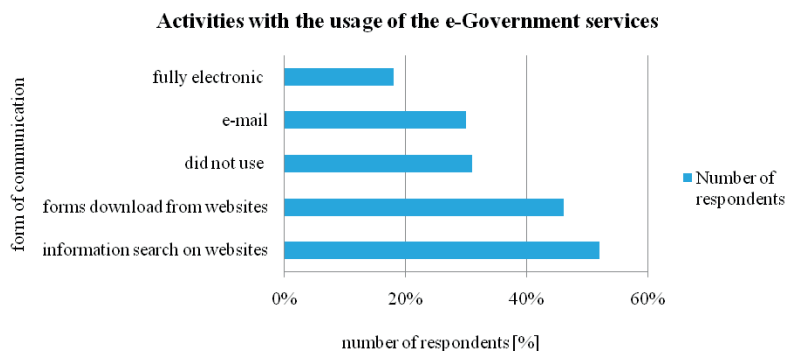

Fig. 4 Activities with the usage of the e-Government services (Source:

[15])

$18 \%$ of respondents communicate with their municipality or city with applications and $40 \%$ of respondents prefer applications which are accessible via smart phone or tablet in communication with the public administration. $76 \%$ of 1012 respondents are regular Internet users who usually use a computer or laptop to connect to the Internet. The Internet is most frequently used to find necessary information for everyday life $(83 \%)$ and to find information about goods and services $(73 \%)$. Compared to previous years citizens prefer more to communicate through social networks, social media, instant messaging and online shopping as well as internet banking. On the contrary, the number of citizens communicating via e-mail has decreased. $40 \%$ of respondents have never heard about e-Government services and the most common form of communication with the public administration authorities remains a personal visit. Citizens use the Internet for the creation of applications for universities, job search and obtain information from the Land Register e. g. abstract of the Title deed. The Internet is least used in the field of property taxes, the change of residence notifications, with personal documents and vehicle registration. The usage of the e-Government services dropped to $38 \%$ in 2014 , compared to 2013 it is a decrease of $8 \%$ [ 15 and 16$]$.

\section{The e-Government services satisfaction index}

A variety of methods are used for the evaluation of satisfaction with provided e-Government services. Authors used one of the most common method - indexes. The calculation was focused on the calculation of the loyalty index and its evolution over time. The loyalty index reveals through the single summary number the general attitude of e-Government services users. The loyalty index includes: the satisfaction index, the recommendation index and the reuse index of the e-Government services in future. Data obtained from a survey carried out in December 2014 by TNS Slovakia on a sample of 1012 citizens were a resource for the calculations [17].

The satisfaction index reflects the subjective feeling of citizens' satisfaction with the provision of the public services 
or official matters online. Stated scales were allocated to answers; the response "certainly satisfied" gained 100 points, "more satisfied" 66 points, "rather dissatisfied" 33 points and "certainly dissatisfied" 0 points.

The recommendation index is an indicator of the experience which respondents gained during the use of the e-Government services and the resulting attitude that either leads to the recommendation to friends to use the e-Government services or not. 100 point scale was again used for the calculation, where 100 is a positive experience and respondent recommends to friends to use the e-Government services and, contrariwise, 0 represents a negative experience and unambiguous nonrecommendation of services to friends.

The reuse index of the e-Government services in the future is to build on the experience of the citizens which they have gained during the use of e-Government services and assess whether the electronic form of official matters led effectively to achieving the target. For the calculation a 100 point scale was used. 100 points reflect the maximum satisfaction and unambiguous decision to use the e-Government services again and 0 points indicates unambiguous rejection of the e-Government services in the future.

The loyalty index

Table 1

\begin{tabular}{|c|c|c|c|c|}
\hline \multirow{2}{*}{ Year } & \multicolumn{4}{|c|}{ Index } \\
\cline { 2 - 5 } & Satisfaction & Future usage & Recommendation & Loyalty \\
\hline 2014 & 72.31 & 83.38 & 79.44 & $\mathbf{7 8 . 3 8}$ \\
\hline 2013 & 65.88 & 81.8 & 75.49 & $\mathbf{7 4 . 3 9}$ \\
\hline 2012 & 68.18 & 79.1 & 77.33 & $\mathbf{7 4 . 8 7}$ \\
\hline 2011 & 63.96 & 68.8 & 70.34 & $\mathbf{6 7 . 7}$ \\
\hline 2010 & 67.07 & 73.86 & 77.77 & $\mathbf{7 2 . 9}$ \\
\hline
\end{tabular}

Source: Authors
Based on the previous findings we can conclude that respondents have rather positive attitude to the e-Government services as shown in Table 1. The loyalty index in 2014 reached 78.38 points out of 100 and compared to 2013 increased by 3.99 points. The loyalty index has currently a growing trend.

\section{Conclusions}

E-Government leads to more effective, citizen oriented public administration and brings time and financial savings for all involved stakeholders. The building and implementation of e-Government in the Slovak Republic face different problems. It is difficult for citizen to understand where to click or what service to search for on the Central portal www.slovensko.sk. Services are hidden under complicated names which are often understandable only to an officer or a programmer. Many e-Government services which are available electronically also require a personal visit to the public administration authority. The development of e-Government should be focused on the modern technologies such as identification through smart phone. The elimination of these and other problems are the responsibility of the newly established Office of the Deputy Prime Minister for investment and informatisation. The Government of the Slovak Republic plans to cooperate with the professional community, enhance communication with non-profit sector and various initiatives which have evaluated the current development rather critically.

\section{Acknowledgement}

This contribution was undertaken as parts of the research projects VEGA 1/0733/15 and VEGA 1/0693/16.

\section{References}

[1] COREJOVA, T. et al.: Regional Dimensions of Knowledge Processes in the Sector of Transport and Logistics and ICT in the Zilina Region. Communications - Scientific Letters of the University of Zilina, vol. 15, No. 2, 2013, 25-33, ISSN 1335-4205.

[2] OECD (2003) The e-Government imperative. Paris, France. pp. 23-25. [Online]. Available: http://www.keepeek.com/Digital-AssetManagement/oecd/governance/the-e-government-imperative_9789264101197-en\#.V965S_mLTIU\#page23

[3] HEEKS, R.: Implementing and Managing eGovernment: An International Text. $1^{\text {st }}$ ed. London: Sage, 2006. ISBN 0761967923.

[4] KEIL, R. et al.: Communication Networks as Base for Mobility - trend Development of Network Architectures. Communications Scientific Letters of the University of Zilina, vol. 17, No. 2, 2015, 80-85, ISSN 1335-4205.

[5] KLOBUCNIK, M., BACIK, V.: Local Self-Government Structure in the EU Member States in 2011. J. of Maps, vol. 12, No. 4, 2016, 671-675.

[6] KRIZANOVA, A., MASAROVA, G., KOLENCIK, J.: The Customer Contentment with Products and Services in Telecommunications Sector in the Slovak Republic. Communications - Scientific Letters of the University of Zilina, vol. 16, No. 2, 51-57, 2014.

[7] MAJERNIK, M., DANESHJO, N., REPKOVA STOFKOVA, K.: Modeling the Process of Business Management Systems Control. Communications - Scientific Letters of the University of Zilina, vol. 18, No. 2, 2016, 93-98, 2016. 


\section{coMMNICaIIONS}

[8] Ministerstvo vnutra SR. ESO - Efektivna, Spolahliva a Otvorena verejna sprava. [Online]. Available: <http://www.minv.sk/?esoefektivna-spolahliva-otvorena-verejna-sprava $>$ )

[9] SAGAT, V., NEMEC, J., KLIMOVSKY, D.: What Kind of Control is Delivered by Regional Self Government in Slovakia. Current Trends in Public Sector Research 2015: Intern. Conference [19 $\left.{ }^{\text {th }}\right]$. Slapanice, 78-83, 2015.

[10] SILCOCK, R.: What is E-government. Parliamentary Affairs, vol. 54, No. 1, 88-101, 2001.

[11] STOFKOVA, K., STOFKOVA, J.: Implementation of the Knowledge Management as a Competitive Advantage. $2^{\text {nd }}$ Intern. conference on education and new learning technologies. Barcelona, 2010, 1323-1328.

[12] European Commission. eGovernment in Slovakia. [Online], pp. 5, 2016. Available: https://joinup.ec.europa.eu/sites/default/ files/ckeditor_files/files/eGovernment\%20in\%20Slovakia\%20-\%20February2016_v1_00.pdf>

[13] SPIRAKIS, G., SPIRAKI CH., NIKOLOPOULOS K.: The Impact of Electronic Government on Democracy: e-democracy through e-participation. Electronic Government, an Intern. J., vol. 7, No. 1, 75-88, 2010.

[14] Internet Live Stats (2016) Slovakia internet users. [Online]. Available: http://www.internetlivestats.com/internet-users/ slovakia/

[15] NASES (2015) Prieskum: Spokojnost s vybranymi e-sluzbami verejnej spravy 2014 - Obcania. [Online], pp. 9-11. Available: http://www.informatizacia.sk/782-menu/20299s

[16] NASES (2016) The Central Government Portal, 2016 [Online]. Available: https://www.slovensko.sk/en/title

[17] WIRTZ, B. W., DAISER, P.: E-Government: Strategy Process Instruments, $1^{\text {st }}$ ed., German University of Administrative Sciences, Speyer, 2015. 